\title{
Involvement of Higher Education in Building Human Resources Character in the Era of Globalization
}

\author{
Ishomuddin $^{1}$ \\ ${ }^{1}$ Department of Sociology, University of Muhammadiyah Malang, Indonesia \\ Correspondence: Department of Sociology, University of Muhammadiyah Malang, Jl. Bandung No. 1 Malang \\ 65113 Jawa Timur, Indonesia. Tel: 623-4155-1253.E-mail: ishom_umm@yahoo.com
}

Received: January 31, 2015

Accepted: July 3, 2015 Online Published: October 28, 2015

doi:10.5539/ies.v8n11p148

URL: http://dx.doi.org/10.5539/ies.v8n11p148

\begin{abstract}
In general, the objectives of this study were to explain the role played by universities in improving its human resources are office holders, lecturers, and students, explain the program what is being done related to the improvement of human resources, and explains the non-academic program to support the implementation of a program that has been prepared so as to ensure the creation of academic atmosphere and moral. This research is using a qualitative approach. Data collection method is observation, in-depth interviews, and documentation. After determining the selected object, it is then determined subjects and informants who serve as a source of information, other than information derived from observation and documents. The data obtained were analyzed using qualitative descriptive. From these results it can be concluded that in the current era of globalization sensitize the managers of private universities to constantly make changes both in management of students, lecturers, and academic. Of the top ten universities in East Java, which is the object of research has done on average conditionally adjustment and in accordance with their respective capabilities to actualize development programs as outlined in the master plan and development plan strategy as a guide.
\end{abstract}

Keywords: high education, human resources, globalization

\section{Introduction}

This article is a summary of the research that has been conducted by researchers at the beginning of 2015 . The purpose of this study were (1) to explain the role played by universities in improving its human resources are office holders, faculty, and students, (2) explain the program what is being done related to the improvement of human resources. (3) explains the non-academic program to support the implementation of a program that has been prepared so as to ensure the creation of academic so as to ensure the creation of academic atmosphere and moral. The third goal is to measure the extent of the college is able to respond to the demands of society and the government to universities, especially to respond to necessities and problems in the face of today's globalized world.

In the world of higher education, globalization will encourage higher education related to the role as a force for economic growth than as a power to find the truth. Definitions, concepts and achievement will be the quality of the bureaucrats-managers authority rather than the authority of the professor of academics. The college will be more focus on the client or customer (Cowen, 1996). These conditions are not always bad actually, but in globalization, the client or customer will have the meaning of "donors" or the ability to help fund for college. The result was predictable, the first that the college will be dominated by families who have wealth and economic capabilities so that the college can not be denied again will become a means of social reproduction. In the next stage, the college will always be dictated by the strength of the college funding that will no longer question the ethical issues of community, social justice and critical assessment. At this stage, in the world of college academics teacher's role in the search for truth will be defeated by the managerial-bureaucratic. The impact of globalization on national education is very large, although it is difficult to pin down the facts and figures. The impact is very clear is that globalization will encourage financial policies based on capitalist that will ultimately keep the education of the population that is economically incapable.

Responsibility to respond to the above conditions are not only imposed by certain groups that are directly related to the world economic market but must be addressed by all parties. World of higher education is the most strategic to prepare personnel educated and skilled relevant and contextual in filling and facing the globalized 
world. Higher education in this case is the universities both public and private should always perform the steps in the progressive education programs so that it is capable of performing its duties and devotion in building a developed and developing nation. In this context, the general aim of this study wanted to see the steps undertaken by higher education in response to globalization. From some of the above problems, the following questions arise: How higher education in Indonesia to face the challenges of globalization? What prepared by the higher education in Indonesia to face the challenges of globalization? And how higher education prepares human resources in this era of globalization?

\section{Literature Review}

\subsection{Era of Globalization}

Globalization is not without consequences. Therefore, we should observe a positive or negative impact of that era. As we see an open world provides new opportunities but also new challenges. Open world is not without protection. Each nation would want their nation to be developed on par with other nations advanced. In line with the pace of world trade, it will be rapidly expanding consumerism. Among the effects of globalization is the emergence of a community of mega-competition where everyone is vying to make the best, achieve the best. World in the era of globalization is the world's pursuit of quality and excellence. With the struggle of the people expected to be dynamic, constantly forward and pursue the best.

In addition to the impact of the positive impact of globalization we also need to look at the negative impacts. The negative effects can manifest themselves in a variety of forms, including threats to the nation's culture. The era of globalization spawned a global culture which is a threat to local culture or the culture of the nation.

In line with the birth of a global culture is the potential for erosion of the identity of a nation. We will see such dangers can arise on the archipelago insight or awareness of the existence of ethnic culture. Twenty first century society as a knowledge society requires every individual to master, or at least have an understanding of the influence of science in life. However, for the mastery of science that does not mean that free people from religious values. Phenomena that arise as a result of the presence of globalization include:

Borderless world. The face of the $21^{\text {st }}$ century is the century of technological advances, especially communication technology that gave birth to a form of a world without borders. This means that communication between humans becomes so easy, so fast and so intense that brick-space limit be annihilated. It is also caused by the destruction of trade barriers between nations relationship with the birth of world free trade so it is likely to be faster collaboration and intensive. Faced with such a condition, then higher education supposedly able to respond academic scholars that gave birth to the master and is able to develop modern science based on the technology of communication and at the same time devoted to God.

The crisis of moral and ethics. Too many events that we can identify as a crisis of morality and ethics that hit the nation. Starting from the financial crisis (e.g. the case of Indonesia) a global variable-triggered events unfolding political crises of morality and ethics even spiritual level. This struck our nation lives in a variety of administrative levels of government, central and local levels and in various state and private sectors. Higher education and religions who hold fast to the faith-based scholars are required to give birth to master the field of science and their knowledge was based on the behaviors that were commendable and well in religious views.

The weakness of the nation's identity. Globalization comes with a variety of faces; peaceful and friendly face or faces fierce. Advances in information technology have prompted the countries and nations of the world into "a world system in terms of politically, socially, and culturally." In this context applies - or perhaps cannot be avoided - the hegemony of the superior world power. Although actually in the governance of global relations are treated the principle of interdependence among countries and nations in the world. Within a framework of this kind of relationship the identity of a nation undergoing a process of fading. Free active political commitment seemed to awkwardly on the world stage, the unity and integrity of the nation in terms of cultural and social experience cracks.

Mega-competition. Globalization wave spawned an open world has changed all aspects of human life both in the life of trade, political, social, cultural as well as the rights and obligations of human beings. The whole force gave birth to what is called the global awareness (global consciousness). Global awareness does not mean that the human crush into particles which are not, but it requires the contribution of each individual in building a new society is a better society. Better society is the result of human achievement and creativity that comes from competition.

Knowledge society. Twenty first century society as a knowledge society requires every individual to master, or at least have an understanding of the influence of science in life. Not that mastery of the science of man freed from 
religious values. But both values-science and religion are complementary, mutually develop and limiting. For the higher education served to close the gap both through scientific studies both religious knowledge and Islamic sciences. The dichotomy between religion and science (science) in the scholarly study had to be terminated. This is where the importance of changing the approach (methodology) and reorientation of religious studies and science (Tilaar, 1998).

\subsection{Paradigms of Human Resource Development}

Facing the era of the basic symptoms of major changes, as now, the management education needs to be based on the paradigm of a clear and precise and consistently followed. At this time there is chaos paradigm between paradigms "whole man" and the paradigm of "human resources". The paradigm of "the whole man" in fact never acquire operational elaboration, and increasingly reduced to the paradigm of "human resources".

The paradigm of human resources is influenced by neoclassical economic theory that sees humans (workers) as a production resource, which is something that is instrumental in achieving production goals. With regard humans as a factor of production, then this paradigm reduce human labor becomes an object, and quietly assumes the existence of human subjects manipulate hidden-object. Subjects hidden it is capitalist. This paradigm has led to the formulation of higher education policy and science and technology biased by the interests of the capitalists in the modern sector, which is to print a human resources professional in the modern sector. Education is oriented towards the acquisition of technical competence that is needed to become professionals or robotic instrument teknostruktur in the modern sector. This paradigm reduces man just a tool, a "something", a very subtle form of dehumanization process wrapped up by the rhetoric of development. Education reduced to training. The demand for graduates ready and policies link and match, if derived from a paradigm of human resources, will accelerate the process of dehumanization (Sudibyo, 2003). Two different paradigms of human portray human differs as follows.

First, the paradigm of "the whole man" saw man not just as a tool or a robot in technology structure, but also as a person, a subject, or "somebody". In addition to the acquisition of technical competence, this paradigm is very critical view of personality development. In fact, the development of the personality is the purpose of education is more important than the acquisition of technical competence. The paradigm of "the whole man" This is in accordance with the Islamic concept of man. In Surat al-Baqarah verse 30 mentions man as vicegerent (khalifah) on earth". Second, the paradigm of "human resources" further emphasize technical competence above other human qualities dimension. The level of devotion is the quality of personality, which refers more to the brightness of the heart rather than the intellect or cognitive and psychomotor abilities.

If the qualitative role of higher education is to print a pious man who is technically competent human--not technically competent and devoted - then, whether the social role of higher education is functionally? Functionally, the social role of higher education is to score three strategic groups is very important, namely: (a) technologists and engineers, who can be called professionals, (b) academics, and (c) scholars.

In terms of quantity, technologists and engineers are most needed by the community. Relatively small demand for academics and scholars will demand even higher. There are differences in understanding of technologists, academics and scholars.

Technologists are experts and professional engineers who are technically running the technocrats are professional leaders that politically technology structure driving. Technologists and engineers are competent in terms of technology, if the technology is given a wide connotation. In broad connotation, technology is the way science weighted to achieve certain goals, so that not only includes the engineering, but also other disciplines such as medicine, pharmacy, management, accounting and administration sciences. This is a technologist and technocrats were included as independent variables in the equation of the production function version of neoclassical economic theory. In their functional relationship was seated as a factor of production? The subject is not stated explicitly in neoclassical economic theory. They are hidden in the implicit assumption that theory. They are capitalists.

Academics are those whose mode of charity is the marketing and promotion of science and technology (teaching function) and deepen the content and expand the horizons of science and technology (research function). They are intelligence agents and rationalization of the nation. In the era of information and high technology, as now, the nation's competitive edge in the global market economy is highly dependent on the quality of their academic charity.

\subsection{Involvement of Higher Education in Developing Human Resources}

The era of globalization is the friction and the interplay between cultural values cannot be avoided. To that end, 
Indonesia is predominantly Muslim must not only be able to survive, but also able to play an active role. If the role of the "last" is likely to lead to isolation, closure and inferiority. Active role (affecting business) will result in transparency and superiority. At least accommodating, ie, adjustment and acceptance of things as far as can be tolerated. Therefore, preparation-both internal and understanding attitude and mentality of his community-must be addressed first.

\subsection{Quality Improvement of Human Resources Responding to Globalization Challenges}

The challenges of globalization which demands earnest attention from all walks of life to face the negative impacts. The first challenge for the world is about the quality of education. In the era of globalization basically appears the era of competition. Speaking of competition is talking about the superman who will survive in a life filled with competition, because it is one of the emerging problems of how to improve the quality of human effort. Establish participatory superman, the man who participated actively in a healthy competition to find the best. The advantages of participatory itself is an obligation to explore and develop the entire human potential to be used in a life filled with competition increasingly sharp.

Therefore, innovation in the field of education is concerned to solve the problem of education. Thus educational innovation is: an idea, goods, methods of perceived or observed as a novelty for a person or group of people (society) either results or invention are used to achieve educational goals or to solve the problem of education.

In today's global era, globalization raises a lot of changes in society. Social change happens is inevitable because of the advancement of science and technology. When it happened the first industrial revolution, human labor is replaced by engine power, of this major impact, among others, on labor, on the need for professional personnel, the need for education to operate the machine as well as the power that will take care of the engine and various other demands. So the change is even more powerful during the second industrial revolution that is replacing the human brain with electronic devices, for example in the form of what we know today with computers. With a lot of computer work that was once done by humans is replaced tools ranging from household activities, shops, offices, schools and various other forms.

Education is always faced with the demands of society requires in order to produce graduates (outputs) of high quality, it is necessary to enter the workforce, but much more important is the ability to have a stock of religious knowledge, morals and character. The balance between science and technology and the faith and piety has been increasingly recognized by society and its efficiency level of effectiveness in the face of modern life.

Public demand for education entering the $21^{\text {st }}$ century today, faced with a situation that is increasingly dynamic and very tight competition. They will exist and function when armed with the knowledge, skills and expertise in a professional manner. Thus education actually functioned as a tool and means to be able to deliver humans reach perfection and well-being. Education is not functional as it is, will be abandoned by society. Therefore, education should always respond and modernize various related elements in them. Related elements in the education system, usually include; educational goals, curriculum, teacher-student, methods and processes of learning, the environment and good evaluation system.

Education of the aspects of management can be seen as a symptom of cultural, economic or as a symptom of the learning process. Conceived as an educational phenomenon, because in it there is a process of learning and the symptoms are symptoms that have short term. While education is understood as a symptom of the real economy because education is to prepare the labor process and usually have a medium term. Then be understood as a symptom of the culture because education is the center of activity for the preservation and continuation of cultural values.

\section{Research Method}

This research is using a qualitative approach, which obtained the data with emphasis on observation and in-depth interview to the position holders in college. The data required is the number of activities carried out by universities in order to increase or impart knowledge to the students and lecturers so as to improve the experience in the academic field. This research was conducted at universities in East Java. The are 323 universities in East Java is 323, with details as follows: 22 public universities, 301 private units. The are 85 private colleges in the form of a university, 116 colleges, 13 Institutes, 9 the Polytechnics, and 78 Academies. Not all colleges are the object of research. Researchers using purposive sampling method with some of the criteria that had been developed earlier by the previous survey. The criteria used are: (1) private universities, (2) a college that has a number of more than 7000 students, (3) a college that has a lot of achievements in the field of the academic and non-academic, and (4) the college is active and access the external research program of the ministry of research and technology and education, this is evidenced by the number of researchers received. In 
this study, there are 10 universities chosen with criteria established by the researchers. The study was conducted using a qualitative approach that is based on the data in the form of observation, in-depth interview, documents and texts in the form of programs strategic plan drawn up by a good college that has been, is and will be implemented. After determining the selected object, it is then determined subjects and informants who serve as a source of information, other than information derived from observation and documents. The data obtained were analyzed using qualitative descriptive.. Once the data is collected and analyzed and concluded to answer the purposes of this study.

Data obtained in the form of academic activities such as research training, expand research and development scheme for faculty and students, the development of cooperation, leadership development program, strengthening the foundation of moral ethics, development of foreign language training, curriculum adjustments, and service development learning tools such as the availability of the Internet and other tools, analyzed by qualitative descriptif. How to analyze is departing from the compiled program, then seen from the indicators and then targets are achieved. This process can be seen from the following findings.

\section{Findings}

Higher education plays a role as well as print quality human resources in the future is always trying to develop institutions both internally and externally.

Table 1. Human resource development program

\begin{tabular}{|c|c|c|c|}
\hline No. & Program Development & Indicator of Activities & Target Achieved \\
\hline 1. & $\begin{array}{l}\text { Visionary Leadership and } \\
\text { reliably. }\end{array}$ & $\begin{array}{l}\text { : Providing, encouraging, and stimulate } \\
\text { activities related to leadership. }\end{array}$ & $\begin{array}{l}\text { : Maternity human } \\
\text { resources and master } \\
\text { graduates qualified } \\
\text { leadership. }\end{array}$ \\
\hline 2. & $\begin{array}{l}\text { Building partnerships with } \\
\text { other institutions. }\end{array}$ & $\begin{array}{l}\text { : Building cooperation with universities and } \\
\text { institutions at home and abroad. Establish the } \\
\text { institutions that manage foreign cooperation. }\end{array}$ & $\begin{array}{l}\text { : Delivery of human } \\
\text { resources and an } \\
\text { extensive network of } \\
\text { graduates. }\end{array}$ \\
\hline 3. & $\begin{array}{l}\text { Strengthening research } \\
\text { activities and publications. }\end{array}$ & $\begin{array}{l}\text { : Providing opportunities for faculty and } \\
\text { students to compete in accessing research } \\
\text { programs. Encouraging faculty and students to } \\
\text { write in journals accredited nationally or } \\
\text { internationally. }\end{array}$ & $\begin{array}{l}\text { : Maternity researchers a } \\
\text { reliable and an increasing } \\
\text { number of publications. }\end{array}$ \\
\hline 4. & $\begin{array}{l}\text { Applying curriculum of } \\
\text { Indonesian National } \\
\text { Quality Framework } \\
\text { (KKNI). }\end{array}$ & Modifying a curriculum based on KKNI. & $\begin{array}{l}\text { : Maternity graduates } \\
\text { relevant to the era of } \\
\text { globalization. }\end{array}$ \\
\hline 5. & $\begin{array}{l}\text { Strengthening the } \\
\text { foundation of moral ethics. }\end{array}$ & $\begin{array}{l}\text { : Conducting special activities related to moral } \\
\text { and ethical guidance. }\end{array}$ & $\begin{array}{l}\text { : Maternity human } \\
\text { resources and moral } \\
\text { graduates. }\end{array}$ \\
\hline 6. & $\begin{array}{l}\text { Leadership development } \\
\text { program. }\end{array}$ & $\begin{array}{l}\text { : Conducting training in the form of a forum } \\
\text { aimed at strengthening the leadership. }\end{array}$ & $\begin{array}{l}\text { : Maternity human } \\
\text { resources and graduates } \\
\text { who have leadership } \\
\text { skills }\end{array}$ \\
\hline 7. & $\begin{array}{l}\text { Reaffirms program of } \\
\text { information technology } \\
\text { (IT) }\end{array}$ & $\begin{array}{l}\text { : Extending and enlarging the Internet network } \\
\text { for faculty and students. Providing training for } \\
\text { faculty and students. }\end{array}$ & : Having knowledge in IT \\
\hline 8. & $\begin{array}{l}\text { Mastering a foreign } \\
\text { language. }\end{array}$ & $\begin{array}{l}\text { : Strengthening training and language education } \\
\text { programs. Increasing the foreign guests. }\end{array}$ & $\begin{array}{l}: \text { Lecturer and students } \\
\text { master a foreign language }\end{array}$ \\
\hline
\end{tabular}




\section{Developing}

9. professionalism.

Increase the recipients.

10.

Expanding and increasing scholarships

Establishing a quality assurance unit of work
: Improving order and discipline in the learning process.

: Building cooperation with other universities are directed towards providing scholarships for faculty or students to obtain scholarships. Providing internal scholarships on a competitive basis.

: Performing an orderly governance in accordance with the ability of the respective colleges. Doing academic control.
: Conducting and discipline in the learning process

: Increasing the recipients of scholarships

: Administration and academic affairs in accordance with the procedure.

\section{Discussion}

The findings of the study as stated in Table 1 above are described as follows:

\subsection{Visionary Leadership and Reliable}

The leader is characterized by; character, charisma, competence and commitment to the institution he leads. Visionary leadership and is able to be reliably driving the dynamics and development of an institution. Leadership includes all lines in a higher education. Electoral college leadership from the rector, vice rector, deans and departments and enhanced increasingly stringent requirements. This phenomenon indicates that the college has begun to pay attention to the quality of human resources that are expected in the management of education produce the best graduates. To prepare graduates who have the provision to the visionary leadership and reliably, university leaders encourage as many activities associated with good leadership cadre conducted by intra and extra organization. All extra activities undertaken by the Organization of student organizations, supported by university leaders.

\subsection{Building Partnerships with Other Agencies}

In the era of globalization is to build a network is a necessity in the development of a higher education. However brilliant an idea initiated by the leaders of a higher education, it would be meaningless if the higher education do not want to build a network. All colleges are now vying to build partnership with other institutions both within and outside the country. The goal, among others, in addition to building imaging also improving the quality of educational resources. This was done in the form of exchange programs of students, faculty, visiting professors, exchange of personnel education, twining programs, and research collaboration.

\subsection{Strengthening Activities Research and Publications}

The greatness of a higher education is determined and measured by how much the quality of research produced by the higher education. Academic research is a compass. The government encourages universities to always be active in taking the role of research and community service. The realization of the impulse is to provide funds that can be used by faculty and students in a competitive manner. One objective of the research program and community service, in addition to helping the community in real terms also spawned national and international publications as possible by the lecturers. Besides, it is very basic and essential in the development of research activities and community service is to change attitudes, behavior and motivation in learning and teaching. Learning conducted by the lecturers expected based on the results of faculty research that has been done.

\subsection{Modifying Old Curricululum to Curriculum of Indonesian National Quality Framework (KKNI)}

National education curriculum designed by the government to products graduates relevant to the world of work has been initiated by the government to respond to today's global world. The curriculum is given the name of the Indonesian National Qualifications Framework. In 2017 all the universities must make changes and implement curriculum based on KKNI. From the research conducted, several universities in East Java have started to prepare and most of them have started applying it to several study programs. Application based curriculum is an important part in the short-term program as outlined in the master plan development.

\subsection{Strengthening the Foundation of Moral Ethics}

The foundation of moral ethics should be grown since its inception, by an increase in the ability of moral judgment on any behavior that would be selected. Programs related to moral development, in addition to be done 
in a container in the field of student affairs student development, in some universities, the program was implemented specifically.

\subsection{Leadership Development Program}

Given educational leadership ability is expected to help to develop ability to be self-sufficient which is characteristic of a person's maturity and leadership skills. The pattern of leadership development among students no longer follows the pattern of local leadership of a region, but has noticed things that apply nationally and even internationally. Such programs not only organized by the Student Council who regularly carry but carried out by groups of students who deliberately driven growth by university leaders.

\subsection{Affirming Program of Information Technology (IT)}

Each college make every effort to make students to master information technology as possible. For that colleges provide facilities such as training, providing internet facilities as much as possible so it can be accessed by students for the purpose of information and learning materials. For students, a growing understanding of information technology is now due to daily needs, tracking the source of knowledge, access to knowledge, research and so on.

\subsection{Mastering a Foreign Language}

The era of globalization requires language skills are more than just a mother tongue that is used daily. For that students must master a foreign language, at least two foreign languages. The efforts made by universities to produce quality graduates are to provide foreign language. Many ways are done by several universities in East Java, among others, is to provide a modern language lab, foreign language learning, brings foreign guests, sit-in programs abroad, and exchange of lecturers or students with lecturers or students of the college in abroad.

\subsection{Developing Professionalism}

Managing the technical aspects are efforts to build awareness for each faculty relating to responsibility for his work as a lecturer and scientific professionalism. The college requires all faculty to do the following: Managing the learning outcomes as academic work under the authority of science, developing human resource commitment of all involved. The parameter is a commitment; honest, caring, and responsible. In practice universities in East Java to develop the professionalism of the entire human resources involved in handling the elements, or elements of higher education as follows: (1) realizing the vision, mission, goals and objectives, (2) planning and institutional programs, (3) the sources of the institution, (4) leadership and rulership (governance), (5) administration, (6) integrity, (7) assessment/evaluation, institutional, (8) admissions, (9) support services to students, (10) faculty: research and academic programs, (11) offers educational programs, (12) general education, that gives an overview of the courses offered in accordance with the vision and mission of higher education, (13) things related to academic, basic competence, certification programs, experiential learning, offers non-credit programs, and so on, (14) study of students' learning progress.

\subsection{Expand and Extend Scholarship}

With so many scholarship programs provided by the government or a foreign institution for higher education in Indonesia, motivate and encourage universities formulate appropriate strategies so that students acquire these programs. For that several universities in East Java set up special units that manage programs abroad. For example, at Muhammadiyah University of Malang this unit or institution is named Internasitional Relations Office (IRO).

\subsection{Forming a Quality Assurance Unit of Work}

Quality assurance unit for each college is a must. One of the tasks of quality assurance is to control and evaluate the implementation of the learning undertaken by lecturers. Some universities in East Java have had a quality assurance unit although the task and its implementation at several universities is not maximized.

\section{Conclusion}

From these results it can be concluded that in the current era of globalization sensitize the managers of private universities to constantly make changes both in management of students, and academic. Of the top ten universities in East Java, which is the object of research has done on average conditionally adjustment and in accordance with their respective capabilities to actualize development programs as outlined in the master plan and development plan strategy as a guide. Program development, indicators of activities and results achieved can be seen in table 1 above. 


\section{Acknowledgments}

With the publication of the article based on this study, researcher thanks the University of Muhammadiyah Malang, especially to the directorate of research and community services who have financed research funding so that it can be completed according to the planned time. Thanks also to all colleagues who have supported and pushed for the publication of research results to this journal.

\section{References}

Akbar, S. (1992). Citra Islam. Jakarta: Erlangga.

Amin, S. (1996). The Future of Globalization. Social Justice, (32).

Backman, M. (2008). Asia Future Shock. Jakarta: Ufuk Press.

Bulliet, R.W. (1972). The Patricians of Nishapur: A Study in Medieval Islamic Social History. Cambridge.

Cowen, R. (1996). Performativity, Post-Modernity and the University. Comparative Education, 32(2), 245-258. http://dx.doi.org/10.1080/03050069628876

Gibson-Graham, J. K. (1996). The End of Capitalism. Canbridge, MA: Blackwell.

Gidden, A. (2000). Jalan Ketiga, Pembaruan Demokrasi Sosial (Centre-Left, The Third Way). Gramedia: Jakarta.

Huntington, S. P. (1966). The Clash of Civilization and Remaking of World Order. New York: Suimon \& Schuster.

Huntington, S. P. (1968). Political Order in Changing Societies. New Haven: Yale University Press.

Inkeles, A. (1960). Industrial Man: The Relation of Status, Experience and Value. American Journal of Sociology, 66(1), 1-31. http://dx.doi.org/10.1086/222819

Ishomuddin. (2014). Some Islamic Higher Education Strategies to Tackle and Take Opportunities in the Era of Globalization. Journal of Education and Practice, 5(15).

Lerner, D. (1958). The Passing of Traditional Society; Modernizing the Middle East. Glencoe III. Free Press.

Levy, M. Jr. (1966). Modernization and Structure of Societies. Princeton: Princeton University Press.

McClelland, D. C. (1961). The Achieving Society. Princeton: Van Nostrand. http://dx.doi.org/10.1037/14359-000

McNeely, C. L. (1995). Constructing the Nation State: International Organization and Perspective Action. Westport: CT, Greenword.

Ritzer, G. (1992). Sociology: A Multiple Paradigm Science (diterjemahkan oleh Alimandan, Sosiologi Ilmu Pengetahuan Berparadigma Ganda). Jakarta: Rajawali Press.

Saul, J. R. (2008). The Collapse of Globalism: and The Reinvention of the World (diterjemahkan Dariyanto, Runtuhnya Globalisme dan Penemuan kembali Dunia). Yogyakarta: Pustaka Pelajar.

Smelser, N. J. (1959). Toward a Theory of Modernization. Social Change in the Industrial Revolution. Chicago: University of Chicago Press.

Sudibyo, B. (2003). Peran PTM dalam Pengembangan Kualitas Manusia dalam Rangka Mencapai Tujuan Persyarikatan, dalam Mencari Format Baru Pengembangan Perguruan Tinggi Muhammadiyah. In S. Tuhuleley, \& M. Afnan (Eds.), Majelis Diktilitbang PP Muhammadiyah.

Tilaar, H. A. R. (1998). Beberapa Agenda Reformasi Pendidikan Nasional dalam Perspektif Abad 21. Magelang: Tera Indonesia.

\section{Copyrights}

Copyright for this article is retained by the author(s), with first publication rights granted to the journal.

This is an open-access article distributed under the terms and conditions of the Creative Commons Attribution license (http://creativecommons.org/licenses/by/3.0/). 